\title{
Indwelling Device
}

National Cancer Institute

\section{Source}

National Cancer Institute. Indwelling Device. NCI Thesaurus. Code C113684.

A device designed to be left in the body for an extended time. 